\title{
Prevalence and associated factors for early interruption of exclusive breastfeeding: meta-analysis on Brazilian epidemiological studies
}

\author{
Marcos Pereira-Santos 1 \\ Moema de Sousa Santana 2 \\ Denise Santana Oliveira 3 \\ Renato Aleixo Nepomuceno Filho 4 \\ Cinthia Soares Lisboa 5 \\ Leila Magda Rodrigues Almeida 6 \\ Daiene Rosa Gomes 7 \\ Valterlinda Alves de Oliveira Queiroz 8 \\ Fran Demétrio 9 \\ Ana Marlúcia Oliveira 10 \\ 1 Centro de Ciências Biológicas e da Saúde. Universidade Federal do Oeste da Bahia. Rua Prof. José Seabra de Lemos, 316. Recanto dos Pássaros. \\ Barreiras, BA, Brasil. CEP: 47.808-021. E-mail: pereira-santosm@bol.com.br \\ 2 Departamento de Alimentos e Nutrição. Universidade Estadual Paulista. São Paulo, SP, Brasil. \\ 3,4,7 Centro de Ciências Biológicas e da Saúde. Universidade Federal do Oeste da Bahia. Barreiras, BA, Brasil. \\ 5,6,9 Centro de Ciências da Saúde. Universidade Federal do Recôncavo da Bahia. Santo Antonio de Jesus, BA, Brasil. \\ 8,10 Escola de Nutrição, Universidade Federal da Bahia, Salvador, BA, Brasil.
}

\begin{abstract}
Objectives: to summarize Brazilian studies that analyzed the risk factors for Exclusive Breastfeeding (EBF) interruption before the child's six months of life.

Methods: systematic review and meta-analysis indexed articles from Bireme, Scielo and Pubmed databases published in the period of January 2000 to December 2015.

Results: 22 articles were included in the meta-analysis. The factors related to newborns were observed, such as birth weight (OR=1.17; CI 95\%: 1.05-1.29), female gender (OR= 1,09; CI 95\%: 1.04-1.13) and the use of pacifier (OR=2.29; CI 95\%: 1.68-2.91) were the main factors responsible for the increase in the occurrence of EBF interruption. The factors were related to the mother, maternal age below twenty years old $(O R=1.22 ; C I$ 95\%: 1.12 1.33) low schooling level $(O R=1.28$; CI 95\%: 1.11-1.45), primiparity $(O R=1.17$; CI 95\%: 1.02-1.32) maternal employment during the postpartum period $(O R=1.26$; $C I$ 95\%: 1.111.41), and low family income (OR=1.22; CI 95\%: 1.08-1.37) contributed significantly to the EBF interruption .

Conclusions: the meta-analysis of Brazilian epidemiological studies demonstrated evidences to conclude that below the age of twenty, low schooling, primiparity, maternal employment in the postpartum period and low family income are associated to the interruption of exclusive breastfeeding until 6 months of age. Children with low birth weight, female gender and used a pacifier had greater vulnerability to not be exclusively breastfed. In conclusion, most of these factors can be modified through appropriate public policies throughout the adequate prenatal period to promote exclusive breastfeeding.
\end{abstract}

Key words Breastfeeding, Exclusive breastfeeding, Child nutrition, Epidemiological surveys, Review 


\section{Introduction}

Evidence from observational studies in several countries have reported that Exclusive Breastfeeding (EBF) in the first six months of life and Complementary Breastfeeding (CBF) for two years or more constitutes of a protective factor for chronic diseases later in life.1,2 The EBF early discontinuation, defined as the abandonment of breastfeeding practice and the utterly or partially replacement of breast milk with other foods before the child is six months old, 1 entails the deprivation of these beneficial elements and may bring damages to the mother and child's health.1-4

The EBF is characterized by a single supply of breast milk, straight from the breast or milked from other sources without providing any other liquids or solids with the exception of drops of syrup or vitamins, oral rehydration salts, mineral supplements or medicine products. ${ }^{1}$ It is emphasized that the EBF practice is recommended by the World Health Organization (WHO) and the Ministry of Health in Brazil (MHB).1,3

A national survey resulted on breastfeeding between 1999 and 2008 found that the median duration of EBF increased from 23.4 to 54.1 days in this period. 5 The survey also identified a similar trend regarding to breastfeeding (BF), which had increased an average of 210 to 341.6 days. 5 These results indicate that, despite the improvement in breastfeeding rates, Brazil still presents $\mathrm{BF}$ and $\mathrm{EBF}$ rates beyond the recommendation proposed by WHO.

Over the past decade, there have been an increasing number of studies on the interruption of exclusive breastfeeding until the age of 6 months. However, none of the meta-analyses were identified in the Brazilian epidemiological literatures relating between socio-cultural and biological risk factors for early interruption of exclusive breastfeeding. Thus, it is pertinent to aggregate evidence and systematize information on the factors of exclusive breastfeeding duration, aiming to provide information to support the planning of future studies and public policies about exclusive breastfeeding in children's health and nutritional fields. ${ }^{2}$ Therefore, the aim of the present study was to summarize Brazilian studies which analyzed the associated factors for early interruption of exclusive breastfeeding.

\section{Methods}

\section{Identification and selection of articles}

A systematic review with meta-analysis was conducted according to the Preferred Reporting Items for Systematic Reviews and Meta-Analyses norms (PRISMA), ${ }^{6}$ on studies that evaluated the main risk factors associated to early interruption of exclusive breastfeeding in Brazil. An online search for published articles was performed in Bireme, Scielo and Pubmed, between January 2000 and December 2015, with the combination of terms used (DeSC/Mesh) in Portuguese, English and Spanish such as: "Breastfeeding", "Weaning" or "Destete" and "Brazil".

Eligible publications were original studies, conducted in different regions in Brazil, which have studied on the factors associated to the interruption of breastfeeding in the first six months of life. The studies that analyzed exclusively the duration of total breastfeeding in the first year of life, early interruption of EBF in newborns under 1 month of age, those with cleft lip and palate, qualitative research studies, items with insufficient data for summarization, review articles, critical and theoretical essays were excluded.

The articles in the databases were selected independently by two reviewers (M Pereira-Santos and LMR Almeida) using forms containing the eligibility criteria to select papers for full text screening. Full texts were independently assessed by these reviewers. Disagreements between both reviewers were solved by consensus.

The eligible articles were read in full, and the information on the year of the publication of the study design prevalence on exclusive breastfeeding, factors associated to early interruption and the association of measurements with the confidence intervals (CI 95\%) were registered using Excel ${ }^{\circledR}$ spreadsheet forms designed to gather the information.

\section{Study quality assessment}

Both authors (M Pereira-Santos and DR Gomes) independently scored the quality of the studies according to the "Effective Public Health Practice Project: Quality Assessment Tool for Quantitative Studies - QATQS" (http://www.ephpp.ca/tools.html) scale which was included in this study. ${ }^{7}$ Five items from this scale were used to assess and classify the studies as "strong," "moderate" or "weak." These items were: 1) selection bias; 2) study design; 3) confounding factors; 4) data collection methods; and 5) type of analysis used for the outcome. At the end of the evaluation, each study received a score according to QATQS scale, it was considered strong if none of the questions had been assessed as weak; moderate, if one of the items was classified as weak; and weak, if there were one or more questions that 
rated as weak. ${ }^{7}$

\section{Statistical analysis}

The variables were associated to the measurements and the confidence intervals were summarized by using the Meta-analysis in Stata 12 (Stata Corp, College Station, TX). The results of the metaanalysis were presented as forest plots.

The summary measurement and its respective confidence interval (CI 95\%) were obtained through a fixed or random-effects model, depending on the heterogeneity among the studies. ${ }^{8}$ Heterogeneity and inconsistency measurements were identified through Cochran's Q statistical test. If heterogeneity was confirmed, then the random-effects model was applied with inverse variance and weight according to the results of the individual studies. ${ }^{9}$ The inconsistency test ( $\mathrm{I} 2>50 \%)$ was used as an indicator for moderate heterogeneity.

\section{Results}

\section{Characteristics of eligible studies}

The search strategy flowchart is shown in Figure 1. 1,326 articles in the database were identified, in which 25 were selected for qualitative synthesis 2,10 33 and 22 were included in the meta-analysis. 2,10 19,21-23,25,27-32 The reasons for the exclusion of the articles were the absence of the association measurements, non-observational study designs, the EBF interruption assessment in groups of adolescent mothers and only breastfeeding analysis in the first month of life.

The main characteristics of the studies included in this review are presented in Table 1. Most articles (57.69\%) were published between 2008 and 2015 , with samples ranging from 168 to 35,000 participants registered in prevalence studies with a sample size over a thousand participants $(42.31 \%)$. In regard to the regions where the surveys were conducted, there was a higher concentration in the Southeast region (53.85\%) in Brazil (Table 1).

By classifying the studies on the design, the predominance of a cross-sectional design (64.0\%) was noted as well as the predominance of the articles with methodological quality was classified as moderate $(72 \%)$. The articles from the cohort studies had higher frequency of strong scores.

The variables most investigated in the studies were birth weight, pacifier use, type of birth, age and maternal schooling level, parity and maternal employment status. Therefore, these variables were included in the meta-analysis and were combined in three blocks: features related to child, maternal and family characteristics.

\section{Meta-analysis results}

In the analyzed period, the average prevalence of EBF in the first six months of a child's life was $25 \%$ (CI95\%: 18.05 - 31.96), and observed the average duration of 55.41 days of EBF (CI95\%: 31,9 78,91) (Table 1).

The meta-analysis results from the factors associated to early interruption can be verified in Table 2. The factors related to newborns as birth weight and pacifier use were the main factors responsible for increasing the interruption of EBF identified in the studies. Thus, newborns with low birth weight had 1.17 more chances (CI95\%: 1,06 - 1.29) early interruption of $\mathrm{EBF}$, and the habit of introducing the pacifier before six months of a child's life increased the chances to 2.30 (CI95\%: 1,68-2.92) of the outcome. The newborn's gender show statistically significant results on the EBF interruption $(\mathrm{OR}=1.09$; CI95\%: $1.05-1.14)$.

As for the factors related to the mother, low schooling level raised to 1.28 ( $\mathrm{OR}=1.28$; $\mathrm{CI} 95 \%$ : 1.11-1.45) the chances of EBF interruption. A similar trend occurred in relation to maternal employment in the postpartum period (OR=1.26; CI95\%: 1.111.41). The fact of being primiparous and at the age of twenty contributed to 1.22 (CI95\%: 1.12- 1.33) and 1.17 (CI95\%: 1.02-1.32) times more to interrupt the occurrence of EBF, respectively.

There was no statistically significant association for cesarean section as a delivery method and also low family income increased the chances of EBF interruption to 1.22 (CI95\%: 1.08-1.37).

\section{Discussion}

The results from the this meta-analysis conducted by Brazilian observational studies published from 2000 to 2015, indicated that the associated factors of EBF interruption were low birth weight, female gender, pacifier use, maternal age less than 20 years old, less than nine years of maternal schooling, primiparity, maternal employment outside the home and low family income.

Among the features related to the child, the birth weight was analyzed in 14 studies, and recorded a statistically significant association between low birth weight and early interruption of EBF. The studies suggest that children with low birth weight have difficulty in starting and maintaining the EBF, as both the frequency and the suction pressure increase according to the increase of the gestational age and the newborn's weight, and they are more prone to 
Figure 1

Flowchart on the search resulting in sources of information, selection and the inclusion of original articles in the systematic review.

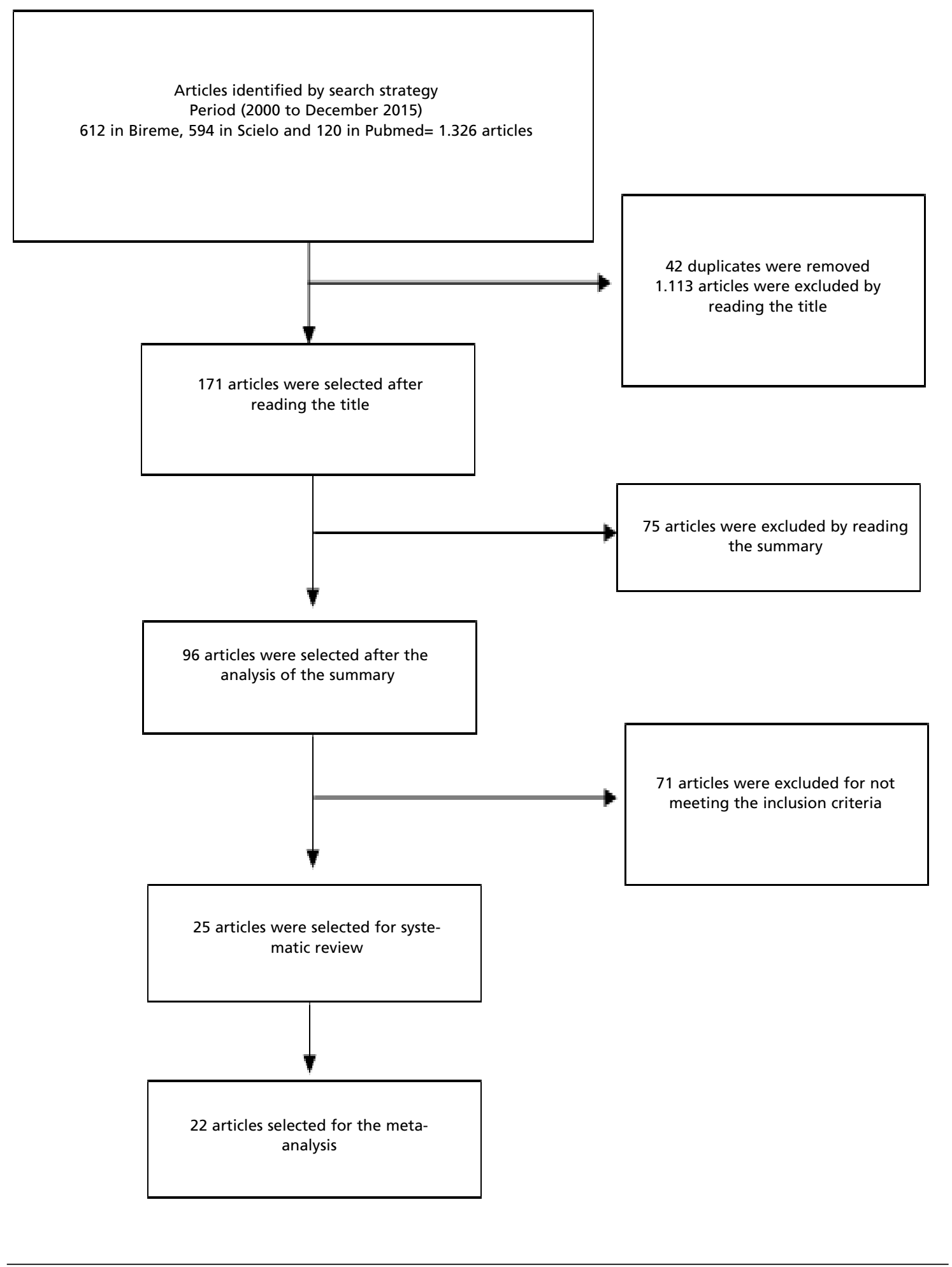


Table 1

Characteristics and meta-analysis study on exclusive breastfeeding in Brazil.

\begin{tabular}{|c|c|c|}
\hline Variables & Number of studies & $\%$ \\
\hline \multicolumn{3}{|l|}{ Year of publication } \\
\hline $2000-2007$ & 11 & 42.3 \\
\hline $2008-2015$ & 15 & 57.6 \\
\hline \multicolumn{3}{|l|}{ Brazil Region } \\
\hline Northeast & 4 & 15.3 \\
\hline North & 1 & 3.8 \\
\hline Midwest & 2 & 7.6 \\
\hline South & 5 & 19.2 \\
\hline Southeast & 14 & 53.8 \\
\hline \multicolumn{3}{|l|}{ Study design } \\
\hline Cross sectional & 16 & 64.0 \\
\hline Cohort & 9 & 36.0 \\
\hline \multicolumn{3}{|l|}{ Sample Size } \\
\hline $168 \dashv 500$ & 7 & 26.9 \\
\hline$>500 \dashv 1000$ & 8 & 30.7 \\
\hline$>1000 \nmid 35,000$ & 11 & 42.3 \\
\hline \multicolumn{3}{|l|}{ QATQS Scores } \\
\hline Weak & 4 & 16.0 \\
\hline Moderate & 18 & 72.0 \\
\hline Strong & 3 & 12.0 \\
\hline Median EBF in Brazil & 55.41 days (CI95\%: $31.9-78.91)$ & \\
\hline EBF Prevalence in Brazil & $25 \%(C 195 \%: 18.05-31.96)$ & \\
\hline $1.6 \% \dashv 11.9 \%$ & 7 & 35.0 \\
\hline $13.3 \% \dashv 30.0 \%$ & 5 & 25.0 \\
\hline $33.2 \% \dashv 58.1 \%$ & 8 & 40.0 \\
\hline
\end{tabular}


Meta-analysis according to the characteristics related to the child, mother and the family, Brazil, 2000-2015.

\begin{tabular}{|c|c|c|c|}
\hline Variables & Number of studies & OR/RP/RR & $I^{2}$ ( $p$ heterogeneity value) \\
\hline \multicolumn{4}{|l|}{ Features relating to child } \\
\hline Low birth weight & 14 & $1.17(1.05-1.29)$ & $0.0 \%(p=0.490)$ \\
\hline Female gender & 5 & $1.09(1.04-1.13)$ & $0.0 \%(p=0.482)$ \\
\hline Pacifier user & 13 & $2.29(1.68-2.91)$ & $92 \%(p<0.001)$ \\
\hline Features relating to Child $\mathrm{D}+\mathrm{L}$ & & $1.25(1.02-1.48)$ & $87 ., 4 \%(p<0.001)$ \\
\hline \multicolumn{4}{|l|}{ pooled OR/RP/RR } \\
\hline \multicolumn{4}{|l|}{ Maternal characteristics } \\
\hline Cesarean section & 14 & $0.96(0 . .26-1.01)$ & $29.0 \%(p=0.139)$ \\
\hline Maternal age $<20$ years & 11 & $1.22(1.12-1.33)$ & $0.0 \% \quad(p=0.750)$ \\
\hline Maternal schooling $<9$ years & 13 & $1.28(1.11-1.45)$ & $74.1 \%(p<0.001)$ \\
\hline Primiparity & 14 & $1.17(1.02-1.32)$ & $67.9 \%(p<0.001)$ \\
\hline Worked in the postpartum period & 9 & $1.26(1.11-1.41)$ & $0.0 \%(p=0.725)$ \\
\hline Maternal Characteristics $D+L$ pooled & & $1.17(1.01-1.33)$ & $90.5 \%(p<0.001)$ \\
\hline \multicolumn{4}{|l|}{ OR/RP/RR } \\
\hline \multicolumn{4}{|l|}{ Family characteristics } \\
\hline Low family income & 4 & $1.22(1.08-1.37)$ & $0.0 \%(p=0.574)$ \\
\hline
\end{tabular}

hospitalization in neonatal unit and become separated from their mothers. Also the female gender variable was associated to early interruption of EBF.

In this meta-analysis, the use of pacifiers was the main factor associated to EBF interruption. A metaanalysis with cohort and cross-sectional studies reported that the use of pacifiers has increased the occurrence of breastfeeding interruption (OR: 2.48; CI95\%: 2.16-2.85). 34 The use of the pacifier may be one of the EBF interruption causes, but also a marker of difficulties related to breastfeeding, as well as reducing maternal motivation to breastfeeding. In addition, mothers who have problems with breastfeeding make its use to ease the child. ${ }^{34}$ It is possible that pacifier use inhibits breastfeeding, sucking reduction may compromise milk production with consequent risk of weaning.

The associations between pacifier use and breastfeeding interruption are causal or not. The pacifier can be introduced prior to complete weaning from breast milk, and not the other way around. Future studies need to take into account their designs to deal with the possibility of reverse causality. ${ }^{34}$

The use of pacifiers is strongly influenced by cultural, motivational and maternal psychological factors. ${ }^{35}$ Qualitative studies are needed to obtain an in depth understanding of reasons behind the intro- duction of pacifier use. 34

In the analyzed studies, male newborns have presented an association to EBF discontinuation. A similar result was observed in Brazilian children, in which there was a higher prevalence of EBF among girls. 5 However, it is not clear whether this high prevalence was due to some cultural aspects, such as the belief that boys need more nutritional support through other foods than breast milk. 36

Among the characteristics related to the mother, it was observed that the parity and maternal age were the most analyzed variables in the studies including this dimension. Both exposures showed a positive and statistically significant association. Thus, primiparous and pregnant women younger than twenty years old have less experience with breastfeeding, which can contribute to the EBF interruption. Thus, it is necessary to establish a closer look at the health team for these women, together in a more qualified prenatal and grounded for a cozy listening in order to encourage EBF. 14

In regard to maternal socio-demographic characteristics, low schooling level, maternal employment during the postpartum period and family income were associated to EBF interruption. Thus, the social inequalities, especially the socioeconomic level, reproduce at a health level. 
The highest degree of women's instruction seems to be a predictive factor of success on EBF practice, which may be related to the increased maternal reliance on the problems and discomforts of breastfeeding. It is most likely for mothers to receive information about the benefits of breastfeeding to generate lower external influence, and the mother may start to reject practices that damages the process of breastfeeding scientifically proven. ${ }^{14}$

Regarding the mother's employment outside the home in the six months of postpartum, they cannot influence on the decision of EBF interruption, it is possible to suggest the imminence to return to work, which becomes inexorable the decision to include precociously other types of milk in the child's feeding scheme, especially cow milk, constraining the success of the supplemented breastfeeding and increasing the median duration of breastfeeding. ${ }^{2}$ Therefore, the six months of maternity leave can contribute to the EBF maintenance. 37 Although women in informal work cannot benefit from this paid leave period, they often have to return to work earlier, in the studies it was not possible to analyze the type of work to identify if the informality is also associated to early interruption of EBF.

As presented in this review, several factors may compromise exclusive breastfeeding. This can be verified in the reported prevalence of $25 \%$ and the median duration of 57 days of EBF. Although the identified values have shown growing trends in the last five years, these values are lower than recommended by WHO, which envisions that $90 \%$ to $100 \%$ of the children under six months of age have breast milk as exclusive food.1,38

The low prevalence of EBF recorded in this study is worrisome, since the EBF positively contributes to maternal and child's health. ${ }^{4}$ Thus, the EBF interruption can bring harm to the health of the child, the mother and increase costs in the Brazilian Unified Health System (SUS), due to the treatment and control of diseases, which may present association to the EBF interruption.

The child's health indicators identify a reduction of infant mortality and morbidity from diarrhea, malnutrition, respiratory diseases, however, on the other hand, these indicators show an increase in chronic diseases such as diabetes and obesity in childhood and adult life. 39,40 Thus, It can be considered that the EBF may effect in later life, as noted in a meta-analysis reported that breastfeeding decreased by $26 \%$ (CI95\%: 22-30) the chance of overweight/obesity and checked protective action for diabetes type 2,39 and in the studies of adult intelli- gence and school performance show evidence of positive effects of EBF on these abilities. 41,42 The same was observed in a cohort study conducted in Brazil, which show that the more enduring the period of breastfeeding in infancy, the higher the levels of intelligence and an average income in adulthood to 30 years. 42

The positive aspects of EBF involving the parent woman establish interface with acceleration of postpartum weight loss, reduce incidence of anemia and reduces the chance of developing breast, ovary and endometrial cancer, as well as osteoporosis. ${ }^{4,43} \mathrm{It}$ is noteworthy that the family economy is affected positively with BF, therefore, there is a significant reduction in spending on acquisition of formulas, bottles, artificial nipples, medicines and food to the newly newborn. 39,44

Our results, although register growing publishing trend in 2008-2015, identify Brazilian scientific literature on the subject is centered in the South and Southeast of the country, where most research centers on breastfeeding in Brazil are located. It is worth adding that most of the studies selected for this review showed moderate quality, with few items of cohort studies. Therefore, the evidence on factors associated to exclusive breastfeeding for children under the age of six months in Brazil found in this review can be considered as moderate. This result corroborates systematic review of previous study. 36

This study has some limitations. It should be considered that various factors such as factors related to the attention of prenatal delivery and postpartum care were not included in this meta-analysis due to the methodological divergence of the analyzed studies and the absence of this information. It adds that most of the studies included in this metaanalysis were a cross-sectional design, which makes it difficult to examine the risk factors for the EBF interruption. Moreover, it was not possible to perform analysis of publication bias, since most studies did not report values of simple frequency of the variables of interest, it is necessary to obtain individual statistical parameters. Therefore, we adopted the strategy to perform the meta-analysis on the measurements referred to the studies analyzed. Despite these limitations, the results of this study report the main factors associated to early interruption of exclusive breastfeeding in studies conducted in Brazil.

In this meta-analysis, both mother and child related variables contributed to the early interruption of exclusive breastfeeding. Among the maternal 
variables were the age below twenty, low schooling level, primiparity, maternal employment in the postpartum period and low family income. While low birth weight, female children who used pacifiers were more likely not to be exclusively breastfed.

\section{References}

1. World Health Organization. Indicators for assessing infant and young child feeding practices. Part 1: definitions. Conclusions of a consensus meeting held 6-8 November 2007 in Washington, DC, USA. Geneva; 2007.

2. Demétrio F, Pinto EJ, Assis AMO. Fatores associados à interrupção precoce do aleitamento materno: um estudo de coorte de nascimento em dois municípios do Recôncavo da Bahia, Brasil. Cad Saúde Pública. 2012; 28 (4): 641-54.

3. Brasil. Ministério da Saúde. Secretaria de Política de Saúde. Organização Pan Americana da Saúde. Guia alimentar para crianças menores de dois anos. Brasília: Ministério da Saúde, 2002. 152 p. (Série A. Normas e Manuais Técnicos; n. 107)

4. Victora CG, Bahl R, Barros AJ, França GV, Horton S, Krasevec J, Murch S, Sankar MJ, Walker N, Rollins NC; Lancet Breastfeeding Series Group. Breastfeeding in the 21st century: epidemiology, mechanisms, and lifelong effect. Lancet. 2016; 387 (10017): 475-90.

5. Brasil. Ministério da Saúde. Secretaria de Atenção a Saúde. Departamento de Ações Programáticas e Estratégicas. II Pesquisa de prevalência de aleitamento materno nas capitais brasileiras e Distrito Federal. Brasília, DF; 2009. v.1. 108 p. (Série C. Projetos, Programas e Relatórios)

6. Moher D, Liberati A, Tetzlaff J, Altman DG. Preferred reporting items for systematic reviews and meta-analyses: the PRISMA statement. Ann Intern Med. 2009; 151: 264-9.

7. National Collaborating Centre for Methods and Tools. Quality Assessment Tool for Quantitative Studies. Hamilton, ON: McMaster University.2008 (cited 2016 April 15). Available from: http://www.ephpp.ca/PDF/ Quality\%20Assessment\%20Tool_2010_2.pdf

8. Harris R, Bradburn M, Deeks J, Harbord R, Altman D, Sterne J. metan: fixed- and random-effects meta-analysis. Stata J 2008; 8: 3-28.

9. Higgins JP, Thompson SG. Quantifying heterogeneity in a meta-analysis. Stat Med. 2002; 21: 1539-58.

10. Audi CAF, Corrêa AMS, Latorre M do RDO. Alimentos complementares e fatores associados ao aleitamento materno e ao aleitamento materno exclusivo em lactentes até 12 meses de vida em Itapira, São Paulo, 1999. Rev Bras Saúde Mater Infant. 2003; 3 (1): 85-93.

11. Bezerra VLVA, Nisiyama AL, Jorge AL, Cardoso RM, Silva EF da, Tristão RM. Aleitamento materno exclusivo e fatores associados a sua interrupção precoce: estudo comparativo entre 1999 e 2008. Rev Paul Pediatr. 2012; 30 (2): 173-9.

12. Caldeira AP, Goulart EMA. Situation of breast-feeding in Montes Claros, Minas Gerais: the study of a representative sample. J Pediatr. 2000 ; 76 (1): 65-72.
Most of these factors can be modified through appropriate public policies throughout the prenatal period with actions to promote exclusive breastfeeding, so that the mother-child relationship can benefit from exclusive breastfeeding.

13. Caminha MF, Batista Filho M, Serva VB, Arruda IKG, Figueiroa JN, Lira PIC. Tendências temporais e fatores associados à duração do aleitamento materno em Pernambuco. Rev Saúde Pública. 2010; 44 (2): 240-8.

14. Carvalhaes MABL, Parada CMGL, Costa MP. Fatores associados à situação do aleitamento materno exclusivo em crianças menores de 4 meses, em Botucatu-SP. Rev LatinoAm Enfermagem. 2007; 15 (1): 62-9.

15. Chaves RG, Lamounier JA, César CC. Fatores associados com a duração do aleitamento materno. J Pediatr. (Rio J.) 2007; 83 (3): 241-6.

16. França GVA, Brunken GS, Silva SM, Escuder MM, Venancio SI. Determinantes da amamentação no primeiro ano de vida em Cuiabá, Mato Grosso. Rev Saúde Pública. 2007; 41 (5): 711-8.

17. Frota DAL, Marcopito LF. Amamentação entre mães adolescentes e não-adolescentes, Montes Claros, MG. Rev Saúde Pública. 2004; 38 (1): 85-92.

18. Gigante DP, Victora CG, Barros FC. Nutrição materna e duração da amamentação em uma coorte de nascimento de Pelotas, RS. Rev Saúde Pública. 2000; 34 (3): 259-65.

19. Kaufmann CC, Albernaz EP, Silveira RB da, Silva MB da, Mascarenhas MLW. Alimentação nos primeiros três meses de vida dos bebês de uma coorte na cidade de Pelotas, Rio Grande do Sul. Rev Paul Pediatr. 2012; 30 (2): 157-65.

20. Leone CR, Sadeck LSR. Fatores de risco associados ao desmame em crianças até seis meses de idade no município de São Paulo. Rev Paul Pediatr. 2012; 30 (1): 21-6.

21. Machado MCM, Assis KF, Oliveira F de CC, Ribeiro AQ, Araújo RMA, Cury AF, Priore SE, Franceschini SC. Determinantes do abandono do aleitamento materno exclusivo: fatores psicossociais. Rev Saúde Pública. 2014; 48 (6): 985-94.

22. Mascarenhas MLW, Albernaz EP, Silva MB, Silveira RB. Prevalência de aleitamento materno exclusivo nos três primeiros meses de vida e seus determinantes no sul do Brasil. J Pediatr. 2006; 82 (4): 289-94.

23. Nascimento MB1, Reis MA, Franco SC, Issler H, Ferraro AA, Grisi SJ. Exclusive breastfeeding in southern Brazil: prevalence and associated factors. Breastfeed Med. 2010; 5 (2): 79-85.

24. Neves ACM, Moura EC, Santos W, Carvalho KMB. Factors associated with exclusive breastfeeding in the Legal Amazon and Northeast regions, Brazil, 2010. Rev Nutr. 2014; 27 (1): 81-95.

25. Oliveira LPM, Assis AMO, Gomes GS da S, Prado MS, Barreto ML. Duração do aleitamento materno, regime alimentar e fatores associados segundo condições de vida em Salvador, Bahia, Brasil. Cad Saúde Pública. 2005; 21(5): 1519-30. 
26. Parizoto GM., Parada CMG de L., Venâncio SI.,Carvalhaes MABL. Tendência e determinantes do aleitamento materno exclusivo em crianças menores de 6 meses. J Pediatr. 2009; 85 (3): 201-8.

27. Passanha A, Benício MD, Venâncio SI, Reis MCG Implantação da Rede Amamenta Brasil e prevalência de aleitamento materno exclusivo. Rev Saúde Pública. 2013; 47 (6): 1141-8

28. Pereira RSV, Oliveira MIC, Andrade CLT, Brito AS. Fatores associados ao aleitamento materno exclusivo: o papel do cuidado na atenção básica. Cad Saúde Pública. 2010; 26(12): 2343-54

29. Queluz MC, Pereira MJB, Santos CB, Leite AM, Ricco RG Prevalência e determinantes do aleitamento materno exclusivo no município de Serrana, São Paulo, Brasil. Rev Esc Enferm USP. 2012; 46 (3): 537-43.

30. Vannuchi MTO, Thomson Z, Escuder MML, TaclaMauren TG M, Vezozzo KMK, Castro LMCP, Oliveira MB Venancio SI . Perfil do aleitamento materno em menores de um ano no Município de Londrina, Paraná. Rev Bras Saúde Mater Infant. 2005; 5 (2): 155-62.

31. Venancio SI, Monteiro CA. Individual and contextual determinants of exclusive breast feeding in São Paulo, Brazil: multilevel analysis. Public Health Nutr. 2006; 9 (1): 40-6.

32. Santo LC, Oliveira LD, Giugliani ER. Factors associated with low incidence of exclusive breastfeeding for the first 6 months. Birth. 2007; 34 (3): 212-9.

33. Bueno MB, Souza JM, Souza SB, Paz SM, Gimeno SG, Siqueira AA. Riscos associados ao processo de desmame entre crianças nascidas em hospital universitário de São Paulo, entre 1998 e 1999: estudo de coorte prospectivo do primeiro ano de vida. Cad Saúde Pública. 2003; 19 (5): 1453-60.

34. Buccini GD, Pérez-Escamilla R, Paulino LM, Araújo CL, Venancio SI. Pacifier use and interruption of exclusive breastfeeding: Systematic review and meta-analysis. Matern Child Nutr. 2016. doi: 10.1111/mcn.12384. [Epub ahead of print]

Received on September 1, 2016

Final version presented on February 6, 2017

Approved on February 10, 2017
35. Cunha AJLA, Leite AM, Machado MM. Aleitamento materno e uso de chupeta: implicações para políticas de saúde. J Pediatr. 2009; 85 (5): 462-3.

36. Boccolini CS, Carvalho ML, Oliveira MIC. Fatores associados ao aleitamento materno exclusivo nos primeiros seis meses de vida no Brasil: revisão sistemática. Rev Saúde Pública. 2015; 49: 91.

37. Brasil. Lei n ${ }^{\circ}$. 11.770/08. Cria o Programa Empresa Cidadã, destinado à prorrogação da licença-maternidade mediante concessão de incentivo fiscal, e altera a Lei $n^{\circ} 8.122$ de 24 de julho de 1991. Diário Oficial da União 2008; 9 set.

38. World Health Organization: Indicators for assessing infant and young child feeding practices. 2008, Washington D.C., USA: WHO, [http://whqlibdoc.who.int/publications/ 2008/9789241596664_eng.pdf]

39. Horta BL, Mola CL, Victora CG. Long-term consequences of breastfeeding on cholesterol, obesity, systolic blood pressure and type 2 diabetes: a systematic review and metaanalysis. Acta Paediatr. 2015; 104: 30-7.

40. Richards M, Hardy R, Wadsworth ME. Long-term effects of breast-feeding in a national birth cohort: educational attainment and midlife cognitive function. Public Health Nutr. 2002; 5: 631-5.

41. Horwood LJ, Fergusson DM. Breastfeeding and later cognitive and academic outcomes. Pediatrics. 1998; 101: E9.

42. Victora CG, Horta BL, Mola CL, Quevedo L, Pinheiro RT, Gigante DP, Gonçalves H, Barros FC. Association between breastfeeding and intelligence, educational attainment, and income at 30 years of age: a prospective birth cohort study from Brazil. Lancet Glob Health. 2015; 3: e199-205.

43. Silva CM, Oliveira Assis AM, Pinheiro SMC, Oliveira LPM, Cruz TRP. Breastfeeding and maternal weight changes during 24 months post-partum: a cohort study. Matern Child Nutr. 2015, 11: 780-91.

44. Toma T, Rea MF. Benefits of breastfeeding for maternal and child health: an essay on the scientific evidence. Cad Saúde Pública. 2008; 24 (2): S235-46. 